Jurnal Manajemen Kesehatan STIKES Yayasan RS. Dr. Soetomo, Vol.2 No. 1, April 2016 : 43-59

\title{
ANALISIS LINGKUNGAN SOSIAL TERHADAP PERILAKU MEROKOK REMAJA DI KECAMATAN PANGARENGAN KABUPATEN SAMPANG MADURA
}

\author{
Diah Wijayanti Sutha * \\ *Dosen D3 RMIK STIKES Yayasan RS Dr. Soetomo \\ Surel : diahwsutha@gmail.com
}

\begin{abstract}
ABSTRAK
Perokok usia remaja dengan rentang usia 14-19 tahun, di Indonesia terus meningkat. Banyak faktor yang menyebabkan mereka merokok di usia muda tersebut, salah satu alasan mereka merokok agar diterima dikalangan kelompoknya yaitu lingkungan sosialnya (keluarga, teman sebaya dan guru yang merokok). Permasalahan ini jelas menjadi topik yang sangat memerlukan perhatian mengingat remaja merupakan generasi penerus bangsa yang nantinya juga menjadi penerus untuk pembangunan negara ini. Tujuan : Menganalisis kondisi lingkungan sosial terhadap perilaku merokok remaja di Kecamatan Pangarengan Kabupaten Sampang. Metode Penelitian: Jenis penelitian adalah explanatory research dengan rancangan belah lintang (cross sectional). Populasi dalam penelitian ini adalah semua pelajar remaja yang berada di Kecamatan Pangarengan Kabupaten Sampang Madura yaitu sebanyak 1.610. Teknik pengambilan sampel dilakukan menggunakan Simple Random Sampling, maka diperoleh sampel penelitian sebesar 214. Analisis data menggunakan Chi Square. Hasil : Variabel lingkungan sosial yang mempunyai hubungan yang signifikan terhadap perilaku merokok adalah semua variabel yang ada yaitu lingkungan keluarga, teman sebaya, guru, idola, dan lingkungan budaya, karena mempunyai nilai $P$ yang lebih kecil dari $\alpha=0,05$.
\end{abstract}

Kata Kunci: Remaja, Perilaku merokok, lingkungan sosial (Keluarga, Teman sebaya, guru, idola, dan budaya)

\section{ABTRACT}

Adolescent smoking behavior (14-19 years) in Indonesia continues to increase. Many of the factors that cause them to smoke at a young age, one of the reasons they smoke in order to be accepted among the group that the social environment (family, peers and teachers who smoke). This issue is obviously a topic that is in need of attention given adolescents are the future generation who will also be the successor to the country's development. Objective: To analyze the social environment on adolescent smoking behavior in District Pangarengan Sampang. Method: This research is explanatory research with cross sectional design (cross-sectional). The population in this study were all students in their adolescents who are in Pangarengan Sampang, Madura as many as 1,610. The sampling technique was performed using Simple Random Sampling, then obtained a sample of 214. The data analysis using Chi Square. Results: Variable social environment has a significant connection to the smoking behavior are all variables which are the family environment, peers, teachers, idols, and cultural environment, because it has a P value less than $\alpha=0.05$.

Keywords: Adolescents, Smoking behavior, social environment (family, peers, teachers, idols, and culture) 


\section{PENDAHULUAN}

Jumlah perokok di Indonesia dalam 30 tahun terakhir meningkat 57 persen. Peningkatan ini merupakan jumlah tertinggi kedua di dunia berdasarkan hasil penelitian The Institute for Health Metrics and Evaluation (IMHE) dan diterbitkan dalam Jurnal Kesehatan Amerika 2014. World Health Organization dalam buku panduan strategi pengendalian bahaya tembakau (MPOWER) menjelaskan bahwa kematian akibat tembakau diseluruh dunia sangat mengejutkan, terdapat 1 kematian setiap 6 detik. Jumlah kematian sebanyak 5,4 juta jiwa pada tahun 2005, sebanyak 100 juta jiwa selama abad ke-20 jika dibiarkan 8 juta jiwa pada tahun 2030 dan 1 miliyar jiwa selama abad ke-21. Riset yang juga telah dipublikasikan dalam Journal of The American Medical Association Januari 2014, menunjukkan bahwa Indonesia merupakan salah satu dari 12 negara yang menyumbangkan angka sebanyak $40 \%$ dari total jumlah perokok dunia. Organisasi Kesehatan Dunia (WHO) menyatakan, tembakau membunuh lebih dari lima juta orang per tahun dan diproyeksikan akan membunuh 10 juta orang sampai tahun 2020, sebanyak $70 \%$ korban berasal dari negara berkembang termasuk Indonesia. Jumlah perokok yang ada di Indonesia mencapai 62,8 juta, sebanyak 40 persen di antaranya berasal dari kalangan ekonomi bawah. (Bustan, 2007).

Indonesia memang diprediksi akan mendapat bonus di tahun 2020-2030 yaitu Bonus Demografi, dimana penduduk dengan umur produktif sangat besar sementara usia muda semakin kecil dan usia lanjut belum banyak. Bonus demografi ini tentu akan membawa dampak sosial ekonomi. Salah satunya adalah menyebabkan angka ketergantungan penduduk, yaitu tingkat penduduk produktif yang menanggung penduduk nonproduktif (usia tua dan anak-anak) akan sangat rendah, diperkirakan mencapai 44 per 100 penduduk produktif. Hal ini sejalan dengan laporan PBB, yang menyatakan bahwa dibandingkan dengan negara Asia lainnya, angka ketergantungan penduduk Indonesia akan terus turun sampai 2020. Tentu saja ini merupakan suatu berkah. Melimpahnya jumlah penduduk usia kerja akan menguntungkan dari sisi pembangunan sehingga dapat memacu pertumbuhan ekonomi ke tingkat yang lebih tinggi. Impasnya adalah meningkatkannya kesejahteraan masyarakat secara keselu-ruhan. Namun, kondisi tersebut bisa saja terjadi sebaliknya. Hal itu bsa terjadi jika angka merokok pada remaja terus meningkat, dimana angka kesakitan remaja juga otomatis meningkat yang nantinya malah akan menjadi beban untuk negara. Melihat angka merokok remaja yang terus meningkat, Indonesia bisa terancam untuk gagal mendapatkan Bonus Demografi tersebut. Remaja merupakan kelompok yang berpotensi berisiko dan perlu mendapat perhatian serius. Terdapat tiga alasan yang melandasi perlunya perhatian tersebut (Shaluhiyah, 2006). Pada masa ini pula beberapa pola perilaku seseorang mulai dibentuk, termasuk identitas diri, kematangan seksual dan keberanian untuk melakukan perilaku berisiko (Shaluhiyah, 2006).

Perilaku merokok remaja merupakan fenomena yang memba-hayakan, dimana dalam hal kuantitas jumlah perokok semakin meningkat, bahkan pada usia muda dan produktif. Sedangakan hal kualitas usia pertamakali merokok juga semakin muda. Banyak faktor yang mempengaruhi semakin banyaknya remaja yang merokok. Pengetahuan dan sikap yang buruk akan bahaya rokok, disamping pengaruh teman dan adanya contoh dari orang dewasa dapat menyebabkan meningkatnya kejadian merokok pada remaja. Secara umum menurut Kurt 
Lewin, perilaku merokok merupakan fungsi dari lingkungan dan individu. Artinya, perilaku merokok selain disebabkan faktor-faktor dari dalam diri, juga disebabkan faktor lingkungan. Faktor dari dalam remaja dapat dilihat dari kajian perkembangan remaja. Remaja mulai merokok dikatakan oleh Erikson (Gatchel, 1989) berkaitan dengan adanya krisis aspek psikososial yang dialami pada masa perkembangannya yaitu masa ketika mereka sedang mencari jati dirinya. Dalam masa remaja ini, sering dilukiskan sebagai masa badai dan topan karena ketidaksesuaian antara perkembangan fisik yang sudah matang dan belum diimbangi oleh perkembangan psikis dan sosial. Upaya-upaya untuk menemukan jati diri tersebut, tidak semua dapat berjalan sesuai dengan harapan masyarakat.

Survey sementara yang dilakukan pada siswa di tiga Sekolah Menengah Pertama (SMP) dan Sekolah Menengah Atas (SMA) yang ada di Kabupaten Sampang yang memiliki rentan umur ratarata 14-18 tahun, sebanyak 9 dari 10 siswa adalah perokok dan 5 diantaranya termasuk dalam golongan perokok berat.
Mereka menghabiskan paling sedikit $>10$ batang rokok setiap harinya, dan konsumsi tersebut bisa bertambah apabila mereka berkumpul bersama teman sesama perokok. Setelah dilakukan wawancara singkat kebanyakan dari para remaja yang merokok dikarenakan ada anggota keluarga mereka yang merokok, begitu juga para teman sebayanya. Remaja perokok di Kabupaten Sampang yaitu 7 dari 10 remaja mengungkapkan bahwa mereka juga ingin terlihat keren seperti apa yang dipaparkan iklan rokok di media yang terjamah oleh mereka apabila mereka merokok.

Hasil studi pendahuluan yang dilakukan pada 20 pelajar di masingmasing kecamatan (10 pelajar laki-laki, 10 pelajar perempuan), yaitu di 5 Kecamatan dari 14 kecamatan yang ada di Kabupaten Sampang terdata sebanyak $90 \%$ pelajar dengan rentan umur 11-18 tahun sudah mempunyai kebiasaan merokok. Survey pendahuluan ini dilakukan di 5 Kecamatan di Kabupaten Sampang yang mempunyai jumlah pelajar terbanyak yaitu Kecamatan Torjun, Pangarengan, Sampang, Banyuates dan Tambelangan.

Tabel 1.1 Data Merokok dan Tidak Merokok Pada Pelajar di Kecamatan Sampang, Torjun, Pangerangan, Banyuates dan Tambelangan (Studi Pendahuluan)

\begin{tabular}{clcccc}
\hline \hline No & Kabupaten & \multicolumn{2}{c}{ Jumlah Pelajar laki-laki } & \multicolumn{2}{c}{ Jumlah Pelajar Perempuan } \\
\cline { 3 - 6 } & Merokok & $\begin{array}{c}\text { Tidak } \\
\text { merokok }\end{array}$ & Merokok & $\begin{array}{c}\text { Tidak } \\
\text { Merokok }\end{array}$ \\
\hline \hline 1 & Sampang & $80 \%$ & $20 \%$ & $20 \%$ & $80 \%$ \\
2 & Torjun & $80 \%$ & $20 \%$ & $10 \%$ & $90 \%$ \\
3 & Pangarengan & $90 \%$ & $10 \%$ & $10 \%$ & $90 \%$ \\
4 & Banyuates & $90 \%$ & $10 \%$ & 0 & $100 \%$ \\
5 & Tambelangan & $70 \%$ & $30 \%$ & 0 & $100 \%$ \\
\hline \hline
\end{tabular}

Tabel 1.1 diatas dapat diuraikan bahwa pelajar perokok dari hasil studi pendahuluan yang dilakukan di 5 Kecamatan di Kabupaten Sampang, Kecamatan Pangarengan menduduki urutan pertama dengan jumlah perokok remaja terbanyak, yaitu $90 \%$ perokok remaja laki-laki dan $10 \%$ perokok remaja perempuan. Hasil studi pendahuluan itulah yang membuat peneliti menargetkan Kecamatan Pangarengan di Kabupaten Sampang sebagai tempat untuk dilakukan penelitian.

Perilaku merokok di Kecamatan Pangarengan dari hasil studi pendahuluan memang mempunyai jumlah perokok yang paling banyak. Perilaku merokok seakan sudah menjadi gaya hidup bagi remaja 
disana. Sebagian dari mereka tahu bahwa merokok akan berbahaya bagi dirinya, namun mereka merasa tidak peduli dengan hal itu. Hasil wawancara mengungkapkan 6 dari 10 pelajar memang sudah merasakan dampak yang mereka terima dari perilaku merokok, yang paling banyak diderita adalah sesak nafas dan batuk-batuk, sisanya belum merasakan apa-apa dan beranggapan bahwa mereka masih sehat.

\section{METODOLOGI PENELITIAN}

Jenis penelitian adalah explanatory research dengan rancangan belah lintang (cross sectional), Lokasi penelitian ini dilakukan di Kecamatan Pangarengan Kabupaten Sampang dikarenakan dari hasil studi pendahuluan banyak remaja yang mempunyai perilaku tidak sehat yang ditandai dengan banyaknya remaja yang memiliki perilaku merokok. Populasi dalam penelitian ini adalah semua pelajar remaja yang berada di Kecamatan Pangarengan Kabupaten Sampang Madura

Dilakukan untuk mencari hubungan antara variabel bebas (Jenis kelamin, usia, tingkat pendidikan, tingkat pengetahuan, perilaku orangtua/anggota keluarga, guru, teman sebaya, idola, budaya, dengan variabel terikat (perilaku merokok). Uji statistik yang digunakan dalam penelitian ini adalah korelasi Chi square. Analisis data kualitatif menggunakan metode perbandingan tetap yaitu secara tetap membandingkan satu datum dengan datum lain dan kemudian secara tetap yaitu sebanyak 1.610 remaja (Data UPTD Kabupaten Sampang, 2013/2014).

Pengambilan sampel dilakukan secara acak dengan kriteria inklusi responden: Remaja putra dan putri dengan rentang usia 13-15 tahun; tidak buta huruf (bisa baca dan tulis); dan ersedia menjadi responden. Teknik pengambilan sampel dilakukan menggunakan Simple Random Sampling. Asumsi tingkat kelonggaran atau ketidaktelitian sebesar 5\% sehingga diperoleh sampel penelitian sebesar 214 responden.

Metode kualitatif dilaksanakan setelah metode kuantitaif selesai dilaksankan/series. Hal ini dillakukan dengan tujuan untuk menggali lebih dalam faktor-faktor yang mempengaruhi perilaku merokok remaja. Data didapatkan melalui wawancara mendalam kepada responden. Analisis diskriptif dilakukan dengan tujuan untuk menggambarkan setiap variabel yang diteliti secara terpisah dengan cara membuat tabel frekuensi atau grafik dari masing-masing variabel. Analisa bivariat membandingkan kategori dengan kategori lainnya. Secara umum proses : Pengumpulan data, Penyederhanaan atau reduksi data, Penyajian data dan Verifikasi simpulan.

\section{HASIL PENELITIAN}

a. Jenis Kelamin

Distribusi frekuensi responden menurut jenis kelamin dapat dilihat pada tabel berikut:

Tabel 1.2 Distribusi Frekuensi Responden berdasarkan Jenis Kelamin

\begin{tabular}{cccc}
\hline No & Jenis Kelamin & f & Persentase \\
\hline \hline 1 & Laki-Laki & 88 & $41,1 \%$ \\
2 & Perempuan & 126 & $58,9 \%$ \\
& Jumlah & 214 & $100 \%$ \\
\hline
\end{tabular}

Tabel 1.2 menggambarkan bahwa sebagian besar responden sebanyak $58,9 \%$ berjenis kelamin perempuan, dan responden berjenis laki-laki sebanyak $41,1 \%$.

b. Usia

Distribusi frekuensi responden menurut usia dapat dilihat pada tabel berikut : 
Tabel 1.3 Distribusi Frekuensi Responden berdasarkan Usia

\begin{tabular}{cccc}
\hline \hline No & Usia & f & Persentase \\
\hline 1 & 11 Tahun & 33 & $15,4 \%$ \\
2 & 12 Tahun & 36 & $16,8 \%$ \\
3 & 13 Tahun & 44 & $20,6 \%$ \\
4 & 14 Tahun & 57 & $26,6 \%$ \\
5 & 15 Tahun & 44 & $20,6 \%$ \\
& Jumlah & 214 & $100 \%$ \\
\hline \hline
\end{tabular}

Tabel 1.3 terlihat bahwa sebagian besar responden berusia 14 tahun (26,6\%), sedangkan kelompok umur yang paling sedikit adalah responden dengan umur 11 tahun yaitu sebesar $15,4 \%$.

Tabel 1.4 Distribusi Frekuensi Responden berdasarkan Tingkat Pendidikan

\begin{tabular}{cccc}
\hline \hline No & $\begin{array}{c}\text { Tingkat } \\
\text { pendidikan }\end{array}$ & $\mathrm{f}$ & Persentase \\
\hline 1 & SD & 52 & $24,3 \%$ \\
2 & MI & 2 & $0,9 \%$ \\
3 & SMP & 99 & $46,3 \%$ \\
4 & MTS & 61 & $28,5 \%$ \\
& Jumlah & 214 & $100 \%$ \\
\hline \hline
\end{tabular}

Tingkat pendidikan responden yang ada saat ini sebagian besar merupakan siswa Sekolah Menengah Pertama (SMP), yaitu sebanyak 46,3\% dan siswa Madrasah Syanawiyah (MTS) sebanyak 28,5, kemudian diikuti oleh responden yang merupakan siswa Sekolah Dasar (SD) sebanyak 24,3\% dan siswa MI sebesar 0,9\%. c. Tingkat Pendidikan Jumlah responden menurut tingkat pendidikan dapat dilihat pada tabel berikut :

\section{Lingkungan Sosial}

a. Perilaku Orangtua/Anggota Keluarga Distribusi frekuensi responden berdasarkan perilaku orangtua/anggota keluarga dapat dilihat pada tabel berikut:

Tabel 1.5 Distribusi Frekuensi Responden berdasarkan Perilaku Orangtua/Anggota Keluarga terhadap Perilaku Merokok

\begin{tabular}{cccc}
\hline No & $\begin{array}{c}\text { Perilaku Anggota } \\
\text { keluarga/Orangtua }\end{array}$ & $\mathrm{f}$ & Persentase \\
\hline \hline 1 & Kurang & 47 & $22.0 \%$ \\
2 & Cukup & 115 & $53.7 \%$ \\
3 & Baik & 52 & $24.3 \%$ \\
4 & Jumlah & 214 & $100 \%$ \\
\hline \hline
\end{tabular}

Perilaku anggota keluaraga/orangtua terhadap terbentuknya perilaku merokok sebagian besar masuk kedalam kategori cukup yaitu 53,7\% dan kategori baik 24,3\%, sedangkan responden pada kategori kurang yaitu sebesar $22,0 \%$. Hasil analisis peneliti berdasarkan jawaban responden terhadap pernyataan favorable dan unfavorable mengenai perilaku 
anggota keluarga/teman terhadap perilaku merokok dapat dilihat pada tabel berikut :

Tabel 1.6 Jawaban Responden Bedasarkan Perilaku Anggota Keluarga/Orangtua

\begin{tabular}{clcc}
\hline \hline No & \multicolumn{1}{c}{ Pernyataan } & Ya & Tidak \\
\hline 1 & $\begin{array}{l}\text { Orangtua pernah menyuruh saya untuk } \\
\text { menjauhi rokok }\end{array}$ & $195(91,1 \%)$ & $19(8,9 \%)$ \\
2 & $\begin{array}{l}\text { Bapak, ibu, adik/kakak kandung, atau orang } \\
\text { lain yang tinggal serumah dengan saya ada }\end{array}$ & $54(25,2 \%)$ & $160(74,8 \%)$ \\
& $\begin{array}{l}\text { yang merokok } \\
\text { Bapak, ibu, adik/kakak kandung, atau orang } \\
\text { lain yang tinggal serumah dengan saya bebas } \\
\text { merokok didepan saya atau orang lain }\end{array}$ & $52(24,3 \%)$ & $162(75,7 \%)$ \\
4 & $\begin{array}{l}\text { Bapak, ibu, adik/kakak kandung, atau orang } \\
\text { lain yang tinggal serumah dengan saya pernah } \\
\text { menawari saya rokok }\end{array}$ & $13(6,1 \%)$ & $201(93,9 \%)$ \\
5 & $\begin{array}{l}\text { Saya akan mendapatkan masalah (dimarahi } \\
\text { orangtua) jika saya merokok }\end{array}$ & $210(98,1 \%)$ & $4(1,9 \%)$ \\
\hline \hline
\end{tabular}

Paparan tabel 1.6 menunjukkan bahwa mayoritas perilaku anggota keluarga/orangtua terhadap perilaku merokok adalah baik. Namun sebanyak $74,8 \%$ orangtua/anggota keluarga responden rata-rata merokok dan sebanyak $75,7 \%$ orangtua/anggota keluarga responden tersebut bebas merokok didepan orang lain bahkan responden sendiri. Adapun hasil peran orangtua/anggota keluarga responden terhadap perilaku merokok dalam hasil wawancara dapat disampaikan sebagai berikut:

"Saya merokok karena orangtua saya merokok mbak, tapi orangtua saya nggak tahu, saya juga sering ambil rokok orang tua saya....."

" saya kalau ketahuan merokok pasti dimarain mbak, ya walaupun bapak ama mas saya ngrokok...."

b. Perilaku Guru

Ditribusi frekuensi responden berdasar perilaku Guru dapat dilihat pada tabel berikut:

Tabel 1.7 Distribusi Frekuensi Responden berdasarkan Perilaku Guru

\begin{tabular}{cccc}
\hline \hline No & Perilaku Guru & f & Persentase \\
\hline \hline 1 & Kurang & - & - \\
2 & Cukup & 209 & $97,7 \%$ \\
3 & Baik & 5 & $2,3 \%$ \\
4 & Jumlah & 214 & $100 \%$ \\
\hline \hline
\end{tabular}

Perilaku guru terhadap perilaku merokok sebagian besar masuk kedalam kategori cukup yaitu 97,7\% dan kategori baik 24,3\%. Sedangkan apabila dilihat lebih mendalam dari hasil jawaban menurut responden terhadap pertanyaan mengenai perilaku guru terhadap perilaku merokok dapat dilihat pada tabel berikut : 
Tabel 1.8 Jawaban Responden terhadap Perilaku Guru

\begin{tabular}{clcc}
\hline \hline No & \multicolumn{1}{c}{ Pernyataan } & Ya & Tidak \\
\hline 1 & Guru saya disekolah ada yang merokok & $104(48,6 \%)$ & $110(51,4 \%)$ \\
2 & $\begin{array}{l}\text { Guru saya terang-terangan merokok didepan } \\
\text { murid }\end{array}$ & $118(55,1 \%)$ & $96(44,9 \%)$ \\
3 & $\begin{array}{l}\text { Guru saya pernah memberi larangan untuk } \\
\text { tidak merokok }\end{array}$ & $101(47,2 \%)$ & $113(52,9 \%)$ \\
4 & $\begin{array}{l}\text { Guru saya pernah mengajar sambil merokok } \\
\text { di kelas }\end{array}$ & $98(45,8 \%)$ & $116(54,2 \%)$ \\
5 & $\begin{array}{l}\text { Guru saya pernah memberikan pelajaran } \\
\text { tentang bahaya merokok }\end{array}$ & $111(51,9 \%)$ & $103(48,1 \%)$ \\
\hline
\end{tabular}

Paparan pada tabel 1.8 memperlihatkan bahwa sebagian besar perilaku guru responden terhadap perilaku merokok sudah baik, sebesar $51,9 \%$ guru pernah memberikan pelajaran tentang bahaya merokok kepada responden dan jumlah guru yang merokok lebih sedikit daripada jumlah guru yang tidak merokok, yaitu sebesar $51,4 \%$ guru yang tidak merokok. Namun sebanyak 55,1\% guru yang merokok tesebut terangterangan merokok didepan murid (responden).

c. Perilaku Teman Sebaya

Ditribusi frekuensi responden berdasar perilaku teman sebaya terhadap perilaku merokok dapat dilihat pada tabel berikut :

Tabel 1.9 Distribusi Frekuensi Responden berdasarkan Perilaku Teman Sebaya

\begin{tabular}{cccc}
\hline \hline No & Perilaku Teman Sebaya & f & Persentase \\
\hline \hline 1 & Kurang & 32 & $15,0 \%$ \\
2 & Cukup & 22 & $10,3 \%$ \\
3 & Baik & 160 & $74,8 \%$ \\
4 & Jumlah & 214 & $100 \%$ \\
\hline
\end{tabular}

Perilaku teman sebaya terhadap perilaku merokok sebagian besar masuk kedalam kategori baik yaitu $74,8 \%$, disusul oleh kategori kurang sebanyak $15,0 \%$, dan terakhir yaitu kategori cukup sebesar $10,3 \%$. Hasil analisis berdasarkan jawaban responden terhadap pernyataan favorable dan unfavorable mengenai perilaku teman sebaya terhadap perilaku merokok dapat dilihat pada tabel berikut :

Tabel 1.10 Jawaban Responden terhadap Perilaku Teman Sebaya

\begin{tabular}{clcc}
\hline \hline No & \multicolumn{1}{c}{ Pernyataan } & Ya & Tidak \\
\hline \hline 1 & Teman saya banyak yang perokok daripada & $32(15 \%)$ & $182(85 \%)$ \\
& $\begin{array}{l}\text { yang tidak merokok } \\
\text { Teman saya pernah menawari saya rokok }\end{array}$ & $42(19,6 \%)$ & $172(80,4 \%)$ \\
3 & $\begin{array}{l}\text { Teman saya banyak yang merokok saat kita } \\
\text { nongkrong bareng }\end{array}$ & $44(20,6 \%)$ & $170(79,4 \%)$ \\
4 & $\begin{array}{l}\text { Teman saya tidak takut merokok didepan } \\
\text { orang dewasa }\end{array}$ & $28(13,1 \%)$ & $186(86,9 \%)$ \\
5 & Teman saya tidak ada satupun yang & $138(64,5 \%)$ & $76(35,5 \%)$ \\
\hline
\end{tabular}


merokok

Paparan pada tabel 1.10 terlihat bahwa sebagian besar responden menyatakan bahwa mereka mempunya leih banyak teman yang tidak merokok ( $85 \%)$, dan juga mereka mempunyai teman yang tidak ada satupun dari teman responden tersebut yang merokok, yaitu sebesar 64,5\%). Namun dilain sisi juga sebagian responden pernah ditawari rokok oleh teman sepermainannya sendiri yaitu sebesar $20,6 \%$ dan juga teman sebaya responden tersebut tidak takut untuk merokok didepan orang dewasa, yaitu sebanyak 13,1\%. Hal ini juga sepaham dengan apa yang disampaikan responden sebagai berikut :

" teman saya tidak takut mbak kalau merokok di depan orang dewasa, biasanya juga teman teman kumpul juga kebanyakan anak-anak SMA, sambil ngopi ngopi sama maen kartu gitu di warung atau di pos kambling (pos ronda)...."

" bisasanya kita patungan beli rokoknya di warung........."

d. Perilaku Idola

Distribusi frekuensi responden berdasarkan perilaku Idola adalah sebagai berikut

Tabel 1.11 Distribusi Frekuensi Responden berdasarkan Perilaku Idola terhadap

Perilaku Merokok

\begin{tabular}{cccc}
\hline \hline No & Perilaku Teman Sebaya & f & Persentase \\
\hline \hline 1 & Baik & 214 & $100 \%$ \\
2 & Jumlah & 214 & $100 \%$ \\
\hline \hline
\end{tabular}

Perilaku idola terhadap perilaku merokok sebagian besar masuk kedalam kategori baik yaitu $100 \%$. Hasil analisis berdasarkan jawaban responden terhadap pernyataan favorable dan unfavorable mengenai perilaku teman sebaya terhadap perilaku merokok dapat dilihat pada tabel berikut :

Tabel 1.12 Jawaban Responden terhadap Perilaku Idola

\begin{tabular}{|c|c|c|c|}
\hline No & Pernyataan & $\mathrm{Ya}$ & Tidak \\
\hline 1 & Saya mempunyai idola yang saya sukai & $214(100 \%)$ & 0 \\
\hline 2 & $\begin{array}{l}\text { Saya sering meniru dan melakukan hal yang } \\
\text { sama dengan idola saya tersebut }\end{array}$ & $201(93,9 \%)$ & $13(6,1 \%)$ \\
\hline 3 & Idola saya merokok & $2(0,9 \%)$ & $212(99,1 \%)$ \\
\hline 4 & $\begin{array}{l}\text { Idola saya pernah menjadi bintang dalam } \\
\text { iklan rokok (atau hal-hal apa saja yang } \\
\text { berkaitan dengan rokok) }\end{array}$ & 0 & $214(100 \%)$ \\
\hline 5 & $\begin{array}{l}\text { Saya sering mencari informasi tentang idol } \\
\text { saya tersebut }\end{array}$ & $198(92,5 \%)$ & $16(7,5 \%)$ \\
\hline
\end{tabular}

Tabel 1.12 terlihat bahwa semua responden mempunyai idola atau tokoh yang menjadi kegemarannya. Setiap respoden mempunyai tokoh idola yang bermacam-macam, mulai dari artis, pemain sepak bola, pemain musik, atau bahkan temannya sendiri dan orangtuanya sendiri. Responden mempunyai berbagai alasan kenapa mereka memilih mengidolakan orang tersebut yang sekarang menjadi idolanya. Hal ini juga sepaham dengan apa yang disampaikan responden sebagai berikut : 
" saya mengidolakan Tores mbak, soalnya besok saya mau jadi pemain sepak bola dan saya suka bola......"

" saya suka ama valentino rossi, pokoknya kalau ada acara balap balapan saya nggak pernah ketinggalan nonton di tivi..."
"Saya suka sama Mas Aldi mbak (pemain Band anak SMA), dia keren ..."(idola yang merokok)

\section{Perilaku Merokok Responden}

Distribusi frekuensi perilaku merokok responden dapat dilihat pada tabel berikut :

Tabel 1.13 Distribusi Frekuensi Perilaku Merokok Responden

\begin{tabular}{clcc}
\hline \hline No & Perilaku Merokok & f & Persentase \\
\hline 1 & Merokok & 32 & $15 \%$ \\
2 & Tidak Merokok & 182 & $85 \%$ \\
& Jumlah & 214 & $100 \%$ \\
\hline \hline
\end{tabular}

Perilaku merokok responden pada remaja yang ada di kecamatan Pangarengan berjumlah 32 remaja dari 214 remaja yang ada dengan persentase $15 \%$. Perilaku merokok yang menjadi kriteria dalam penelitian ini adalah responden yang saat ini menjadi perokok atau sebelumnya pernah mencoba merokok. Perilaku merokok tersebut dilakukan oleh responden di

Tabel 1.14 Hubungan antara Jenis Kelamin dengan Perilaku Merokok

\begin{tabular}{llcccccc}
\hline \hline No & $\begin{array}{c}\text { Jenis } \\
\text { Kelamin }\end{array}$ & \multicolumn{3}{c}{ Perilaku Merokok } & \multicolumn{3}{c}{ Total } \\
\cline { 3 - 8 } & Merokok & $\%$ & $\begin{array}{c}\text { Tidak } \\
\text { Merokok }\end{array}$ & $\%$ & $\mathrm{f}$ & $\%$ \\
\hline \hline 1 & Laki-Laki & 32 & $36,4 \%$ & 56 & $63,6 \%$ & 88 & $100 \%$ \\
2 & Perempuan & 0 & $0,0 \%$ & 126 & $100 \%$ & 126 & $100 \%$ \\
& Jumlah & 32 & $15 \%$ & 182 & $85 \%$ & 214 & $100 \%$ \\
\hline \hline$X^{2}=0,000 \alpha=0,05$ & & & & & &
\end{tabular}

Hasil analisa bivariat antara jenis kelamin dengan perilaku merokok yang tertulis pada tabel 5.11 menyatakan bahwa ada hubungan antara jenis kelamin dengan perilaku merokok, nilai $X^{2}=0,000<\alpha=0,05$. Sampai saat penelitian dilakukan, ada 32 responden remaja laki-laki $(36,4 \%)$ yang merokok. Data diatas menggambarkan bahwa rentan usia 11 tahun sampai dengan usia 15 tahun.

A. Hubungan karakteristik individu dengan perilaku merokok

1. Hubungan antara jenis kelamin dengan perilaku merokok

Hasil uji hubungan antara jenis kelamin dengan perilaku merokok dapat dilihat pada tabel silang berikut : perilaku merokok, baik yang saat ini masih merokok maupun pernah mencoba merokok, semua dilakukan oleh remaja laki-laki.

2. Hubungan Tingkat Pendidikan dengan perilaku merokok

Hasil uji hubungan antara tingkat pendidikan dengan perilaku merokok dapat dilihat pada tabel silang berikut :

Tabel 1.15 Hubungan antara Tingkat Pendidikan dengan Perilaku Merokok

\begin{tabular}{llcccccc}
\hline \hline No & $\begin{array}{c}\text { Tingkat } \\
\text { Pendidikan }\end{array}$ & \multicolumn{3}{c}{ Perilaku Merokok } & \multicolumn{2}{c}{ Total } \\
\cline { 2 - 7 } & Merokok & $\%$ & $\begin{array}{c}\text { Tidak } \\
\text { Merokok }\end{array}$ & $\%$ & $\mathrm{f}$ & $\%$ \\
\hline \hline 1 & SD & 7 & $13,5 \%$ & 45 & $86,5 \%$ & 52 & $100 \%$ \\
2 & MI & 1 & $50,0 \%$ & 1 & $50,0 \%$ & 2 & $100 \%$ \\
3 & SMP & 17 & $17,2 \%$ & 82 & $82,8 \%$ & 99 & $100 \%$
\end{tabular}




\begin{tabular}{llcccccc}
\hline \hline No & $\begin{array}{c}\text { Tingkat } \\
\text { Pendidikan }\end{array}$ & \multicolumn{3}{c}{ Perilaku Merokok } & \multicolumn{3}{c}{ Total } \\
\cline { 2 - 8 } & Merokok & $\%$ & $\begin{array}{c}\text { Tidak } \\
\text { Merokok }\end{array}$ & $\%$ & $\mathrm{f}$ & $\%$ \\
\hline 4 & MTS & 7 & $11,5 \%$ & 54 & $88,5 \%$ & 61 & $100 \%$ \\
& Jumlah & 32 & $15,0 \%$ & 182 & $85,0 \%$ & 214 & $100 \%$ \\
\hline \hline$X^{2}=0,394 \alpha=0,05$ & & & & & &
\end{tabular}

Hasil analisa bivariat antara tingkat pendidikan responden dengan perilaku merokok yang tertulis pada tabel 1.12 menyatakan bahwa tidak ada hubungan antara tingkat pendidikan individu dengan perilaku merokok, nilai $X^{2}=$ $0,394>\alpha=0,05$.

Tabel 1.16 Hubungan antara Usia dengan Perilaku Merokok

\begin{tabular}{cccccccc}
\hline \hline No & Usia & \multicolumn{4}{c}{ Perilaku Merokok } & \multicolumn{2}{c}{ Total } \\
\cline { 3 - 8 } & & Merokok & $\%$ & Tidak Merokok & $\%$ & $\mathrm{f}$ & $\%$ \\
\hline 1 & 11 Tahun & 3 & $9,1 \%$ & 30 & $90,9 \%$ & 33 & $100 \%$ \\
2 & 12 Tahun & 6 & $16,7 \%$ & 30 & $83,3 \%$ & 36 & $100 \%$ \\
3 & 13 Tahun & 4 & $9,1 \%$ & 40 & $37,4 \%$ & 44 & $100 \%$ \\
4 & 14 Tahun & 8 & $14,0 \%$ & 49 & $86,0 \%$ & 57 & $100 \%$ \\
5 & 15 Tahun & 11 & $25,0 \%$ & 33 & $75,5 \%$ & 44 & $100 \%$ \\
& Jumlah & 32 & $15,0 \%$ & 182 & $85,0 \%$ & 214 & $100 \%$ \\
\hline \hline$X^{2}=0,223 \alpha=0,05$ & & & & & \\
\hline
\end{tabular}

Hasil analisa bivariat antara usia dengan perilaku merokok yang tertulis pada tabel 1.13 menyatakan bahwa tidak ada hubungan antara usia dengan perilaku merokok, nilai $X^{2}=0,223>\alpha=0,05$. Dari data diatas dapat dilihat bahwa semakin bertambahnya usia semakin banyak remaja yang merokok. Usia 11 tahun responden masih berada di bangku sekolah dasar dan mempunyai perilaku merokok, hal ini dikuatkan dengan pernyataan bahwa sebagian responden menyebutkan bahwa usia pertama kali mencoba merokok yaitu

\section{Hubungan antara Usia dengan Perilaku Merokok}

Hasil uji hubungan antara usia dengan perilaku merokok dapat dilihat pada tabel silang berikut :

Tabel 1.17 Hubungan antara Anggota Keluarga/Orangtua dengan Perilaku Merokok

\begin{tabular}{|c|c|c|c|c|c|c|c|}
\hline \multirow[t]{2}{*}{ No } & \multirow{2}{*}{$\begin{array}{l}\text { Perilaku } \\
\text { Anggota } \\
\text { Keluarga }\end{array}$} & \multicolumn{4}{|c|}{ Perilaku Merokok } & \multicolumn{2}{|c|}{ Total } \\
\hline & & Merokok & $\%$ & $\begin{array}{c}\text { Tidak } \\
\text { Merokok }\end{array}$ & $\%$ & $\mathrm{f}$ & $\%$ \\
\hline 1 & Kurang & 29 & $61,7 \%$ & 18 & $38,3 \%$ & 47 & $100 \%$ \\
\hline 2 & Cukup & 3 & $2,6 \%$ & 112 & $97,4 \%$ & 115 & $100 \%$ \\
\hline 3 & Baik & 0 & $0 \%$ & 52 & $100 \%$ & 52 & $100 \%$ \\
\hline & Jumlah & 32 & $15,0 \%$ & 182 & $85,0 \%$ & 214 & $100 \%$ \\
\hline & $000 \alpha=0$, & & & & & & \\
\hline
\end{tabular}


Hasil analisa bivariat antara anggota keluarga/orangtua dengan perilaku merokok yang tertulis pada tabel 5.24 menyatakan bahwa ada hubungan antara anggota keluarga/orangtua dengan perilaku merokok, nilai $X^{2}=$ $0,000<\alpha=0,05$.

b. Hubungan antara perilaku teman sebaya dengan perilaku merokok
Hasil uji hubungan antara teman sebaya dengan perilaku merokok dapat dilihat pada tabel silang berikut :

Tabel 1.18 Hubungan antara Perilaku Teman Sebaya dengan Perilaku Merokok

\begin{tabular}{llcccccc}
\hline \hline No & $\begin{array}{c}\text { Perilaku } \\
\text { Teman } \\
\text { Sebaya }\end{array}$ & \multicolumn{3}{c}{ Perilaku Merokok } & \multicolumn{3}{c}{ Total } \\
\cline { 3 - 8 } & Kerokok & $\%$ & $\begin{array}{c}\text { Tidak } \\
\text { Merokok }\end{array}$ & $\%$ & $\mathrm{f}$ & $\%$ \\
\hline \hline 1 & Kurang & 31 & $96,9 \%$ & 1 & $3,1 \%$ & 32 & $100 \%$ \\
3 & Cukup & 1 & $4,5 \%$ & 21 & $95,5 \%$ & 22 & $100 \%$ \\
& Baik & 0 & $0 \%$ & 160 & $100 \%$ & 160 & $100 \%$ \\
& Jumlah & 32 & $15,0 \%$ & 182 & $85,0 \%$ & 214 & $100 \%$ \\
\hline \hline$X^{2}=0,000 \alpha=0,05$ & & & & & \\
\hline
\end{tabular}

Hasil analisa bivariat antara teman sebaya dengan perilaku merokok yang tertulis pada tabel 1.15 menyatakan bahwa ada hubungan antara perilaku teman sebaya dengan perilaku merokok, nilai $X^{2}=0,000<\alpha=0,05$. c. Hubungan antara Perilaku Guru dengan perilaku merokok

Hasil uji hubungan antara guru dengan perilaku merokok dapat dilihat pada tabel silang berikut :

Tabel 1.19 Hubungan antara Perilaku Guru dengan Perilaku Merokok

\begin{tabular}{llcccccc}
\hline \hline No & $\begin{array}{c}\text { Perilaku } \\
\text { Guru }\end{array}$ & \multicolumn{3}{c}{ Perilaku Merokok } & \multicolumn{2}{c}{ Total } \\
\cline { 3 - 7 } & Merokok & $\%$ & $\begin{array}{c}\text { Tidak } \\
\text { Merokok }\end{array}$ & $\%$ & $\mathrm{f}$ & $\%$ \\
\hline \hline 1 & Kurang & 0 & $0 \%$ & 0 & $0 \%$ & 0 & $0 \%$ \\
2 & Cukup & 32 & $15,3 \%$ & 177 & $84,7 \%$ & 209 & $100 \%$ \\
3 & Baik & 0 & $0 \%$ & 5 & $100 \%$ & 5 & $100 \%$ \\
& Jumlah & 32 & $15,0 \%$ & 182 & $85,0 \%$ & 214 & $100 \%$ \\
\hline$X^{2}=0,343 \alpha=0,05$ & \multicolumn{7}{c}{} \\
\hline \hline
\end{tabular}

Hasil analisa bivariat antara perilakuguru dengan perilaku merokok yang tertulis pada tabel 1.16 menyatakan bahwa ada hubungan antara perilaku guru dengan perilaku merokok, nilai $X^{2}=0,000<\alpha=0,05$.

d. Hubungan antara Perilaku Idola dengan Perilaku Merokok

Hasil uji hubungan antara idola dengan perilaku merokok dapat dilihat pada tabel silang berikut : 
Tabel 1.20 Hubungan antara Idola dengan Perilaku Merokok

\begin{tabular}{llcccccc}
\hline \hline No & $\begin{array}{c}\text { Perilaku } \\
\text { Idola }\end{array}$ & \multicolumn{3}{c}{ Perilaku Merokok } & \multicolumn{2}{c}{ Total } \\
\cline { 3 - 7 } & Merokok & $\%$ & $\begin{array}{c}\text { Tidak } \\
\text { Merokok }\end{array}$ & $\%$ & $\mathrm{f}$ & $\%$ \\
\hline 1 & Kurang & 0 & $0 \%$ & 0 & $0 \%$ & 0 & $0 \%$ \\
2 & Cukup & 0 & $0 \%$ & 0 & $0 \%$ & 0 & $100 \%$ \\
3 & Baik & 32 & $15,5 \%$ & 182 & $85,0 \%$ & 214 & $100 \%$ \\
& Jumlah & 32 & $15,0 \%$ & 182 & $85,0 \%$ & 214 & $100 \%$ \\
\hline \hline
\end{tabular}

Hasil analisa bivariat antara perilaku idola dengan perilaku merokok yang tertulis pada tabel 1.17 menyatakan bahwa tidak ada hubungan antara perilaku idola dengan perilaku merokok, nilai $X^{2}=0,777>\alpha=0,05$. e. Hubungan antara Budaya dengan Perilaku Merokok

Hasil uji hubungan antara budaya dengan perilaku merokok dapat dilihat pada tabel silang berikut :

Tabel 1.21 Hubungan antara Budaya dengan Perilaku Merokok

\begin{tabular}{lccccccc}
\hline \hline \multirow{2}{*}{ No } & $\begin{array}{c}\text { Perilaku } \\
\text { Idola }\end{array}$ & \multicolumn{3}{c}{ Perilaku Merokok } & \multicolumn{2}{c}{ Total } \\
\cline { 3 - 8 } & Merokok & $\%$ & $\begin{array}{c}\text { Tidak } \\
\text { Merokok }\end{array}$ & $\%$ & $\mathrm{f}$ & $\%$ \\
\hline 1 & Kurang & 11 & $91,7 \%$ & 1 & $8,3 \%$ & 12 & $100 \%$ \\
2 & Cukup & 13 & $28,3 \%$ & 33 & $71,7 \%$ & 46 & $100 \%$ \\
3 & Baik & 8 & $5,1 \%$ & 148 & $94,9 \%$ & 156 & $100 \%$ \\
& Jumlah & 32 & $15,0 \%$ & 182 & $85,0 \%$ & 214 & $100 \%$ \\
\hline \hline$X^{2}=0,000 \alpha=0,05$ & & & & & & \\
\hline \hline
\end{tabular}

Hasil analisa bivariat antara budaya dengan perilaku merokok yang tertulis pada tabel 1.18 menyatakan bahwa ada hubungan antara budaya dengan perilaku merokok, nilai $X^{2}=$ $0,000<\alpha=0,05$.

\section{PEMBAHASAN}

Patut diperhatikan bahwa belakangan ini kejadian merokok meningkat pada remaja wanita. Wanita perokok dilaporkan menjadi percaya diri, suka menentang, dan secara sosial cakap, keadaan ini berbeda dengan perokok lakilaki yang secara sosial tidak aman. Pada saat ini, peningkatan kejadian merokok tidak hanya terjadi pada remaja laki-laki. Begitupun dengan wanita, wanita yang merokok dilaporkan menjadi percaya diri, suka menentang dan mandiri. Namun pada kasus ini karena pengaruh adanya budaya yang menganggap bahwa merokok merupakan hal yang sangat tercela untuk perempuan, hal ini menekan tumbuhnya perokok perumpuan yang ada di daerah peneliti.

Dari segi pendidikan, sebagian besar responden saat ini menumpuh jenjang pendidikan di Sekoah Menengah Pertama (SMP) yaitu sebsar 46,3\%. Pendidikan responden yang ada saat ini sebagian besar merupakan siswa Sekolah Menengah Pertama (SMP), yaitu sebanyak 46,3\% dan siswa Madrasah Syanawiyah (MTS) sebanyak 28,5, kemudian diikuti oleh responden yang merupakan siswa Sekolah Dasar (SD) sebanyak 24,3\% dan siswa MI sebesar 0,9\%. Berdasarkan uji statistik dengan uji ch square ternyata tidak ada hubungan antara tingkat pendidikan dengan perilaku merokok pada remaja. Hal ini sejalan dengan penelitian Bagio (2009) 
yang menyatakan bahwa pendidikan tidak berhubungan dengan perilaku merokok seseorang. Pada aman sekarang orang cenderung merokok jika mereka suka, dan tidak peduli saat ini dia berstatus sebagai pelajar ataupun penganggurab. Rokok sudah membius ke semua kalangan, bahkan orang yang mempunyai pengetahuan tinggipun dapat terpengaruh untuk terjerumus ke perilaku merokok.

\section{Lingkungan Sosial dengan Perilaku Merokok}

Dari segi lingkungan sosial responden di Kecamatan Pangarengan Kabupaten Sampang yang terdiri dari lingkungan keluarga, lingkungan sekolah, dan lingkungan bermain responden semua mempunyai peranan yang sangat penting untuk terbentuknya perilaku merokok pada remaja saat ini.Lingkungan sering disebut environment atau juga disebut nature. Lingkungan dalam pengertian psikologi adalah segala apa yang berpengaruh pada diri individu dalam berperilaku. Lingkungan turut berpengaruh terhadap perkembangan pembawaan dan kehidupan manusia.

\section{a. Perilaku Anggota Keluarga/ Orangtua}

Hasil penelitian menunjukkan sebagian besar responden mempunyai perilaku anggota keluarga/ orangtua yang cukup yaitu sebesar $53,7 \%$ dan baik sebesar 24,3\%. Walau separuh lebih perilaku anggota keluarga/orangtua tergolong kedalam kaategori cukup, namun masih ada hal esensial tentag perilaku mereka terhadap perilaku merokok yang tentunya berkontribusi terhadap timbulnya perilaku merokok pada responden. Sebesar $74,8 \%$ anggota keluarag/orangtua responden mempunyai kebiasaan merokok, dan sebanyak $6,1 \%$ dari anggota keluarga responden pernah menawari responden merokok.

Dilingkungan keluarga dari hasil analisa bivariat antara anggota keluarga/orangtua dengan perilaku merokok dalam hasil peneltian menyatakan bahwa ada hubungan yang signifikan antara anggota keluarga/ orangtua dengan perilaku merokok, nilai $X^{2}=0,000<\alpha=0,05$. Hal ini sepandapat dengan salah satu temuan tentang remaja perokok adalah bahwa anak-anak muda yang berasal dari rumah tangga yang tidak bahagia, di mana orang tua tidak begitu memperhatikan anak-anaknya dan memberikan hukuman fisik yang keras, lebih mudah untuk menjadi perokok dibandingkan dengan anak-anak muda yang berasal dari lingkungan rumah tangga yang bahagia (Baer dan Corado dalam Atkinson, 1999). Anak-anak dengan orangtua perokok cenderung akan merokok dikemudian hari, hal ini terjadi paling sedikit disebabkan oleh karena dua hal: Pertama, karena anak tersebut ingin seperti bapaknya yang kelihatan gagah dan dewasa saat merokok. Kedua, karena anak sudah terbiasa dengan asap rokok dirumah, dengan kata lain disaat kecil mereka telah menjadi perokok pasif dan sesudah remaja anak gampang saja beralih menjadi perokok aktif.

Remaja yang berasal dari keluarga konservatif yang menekankan nilai-nilai sosial dan agama dengan baik dengan tujuan jangka panjang lebih sulit untuk terlibat dengan rokok/tembakau/obatobatan dibandingkan dengan keluarga yang permisif dengan penekanan pada falsafah "kerjakan urusanmu sendirisendiri". Paling kuat pengaruhnya adalah bila orang tua sendiri menjadi figur contoh, yaitu sebagai perokok berat, maka anak-anaknya akan mungkin sekali untuk mencontohnya. Perilaku merokok lebih banyak ditemui pada mereka yang tinggal dengan satu orang tua (single parent). Daripada ayah yang perkok, remaja akan lebih cepat berperilaku sebagai perokok justru bila ibu mereka yang merokok, hal ini lebih terlihat pada remaja putri.

Pada dasarnya perilaku merokok adalah perilaku yang dipelajari. Hal itu berarti ada fihak-fihak yang berpengaruh besar dalam proses sosialisasi. Konsep sosialisasi pertama berkembang dari 
Sosiologi dan Psikologi Sosial merupakan suatu proses tranmisi nilai-nilai, sistem belief, sikap, atau pun perilakuperilaku dari generasi sebelumnya kepada generasi berikutnya (Durkin, 1995). Adapun tujuan sosialisasi ini adalah agar generasi berikutnya mempunyai sistem nilai yang sesuai dengan tuntutan norma yang diinginkan oleh kelompok, sehingga individu dapat diterima dalam suatu kelompok. Dalam kaitannya dengan perilaku merokok, pada dasarnya hampir tidak ada orang tua yang menginginkan anaknya untuk menjadi perokok bahkan masyarakat tidak menuntut anggota masyarakat untuk menjadi perokok. Namun demikian, dalam kaitan ini secara tidak sadar, ada beberapa agen yang merupakan model dan penguat bagi perokok remaja.

\section{Perilaku Teman Sebaya}

Merokok ditujukan untuk mengikuti kebiasaan kelompok, identifikasi dengan perokok lain, dan untuk menentukan image diri seseorang. Merokok pada anak-anak juga dapat disebabkan adanya paksaan dari teman-temannya.masa remaja disebut juga sebagai periode peralihan, periode perubahan, periode bermasalah, periode pencarian identitas, dan periode tidak realistik. Pada periode pencarian identitas, remaja yang tidak ingin lagi disebut sebagai anak-anak, berusaha menampilkan atau mengidentifikasi perilaku yang menjadi simbol status kedewasaan. Salah satu perilaku yang muncul adalah perilaku merokok yang mereka anggap sebagai simbol kematangan, dimana perilaku ini seringkali dimulai pada usia sekolah menengah pertama.

Usaha remaja untuk memperoleh kebebasan emosional sering disertai perilaku "pemberontakan" dan melawan keinginan orangtua. Bila tugas perkembangan ini sering menimbulkan pertentangan dalam keluarga dan tidak dapat diselesaikan di rumah, maka remaja akan mencari jalan keluar dan ketenangan di luar rumah. Hal tersebut tentunya akan membuat remaja memiliki kebebasan emosional dari luar orangtua sehingga remaja justru lebih percaya pada temantemannya yang senasib dengannya. Remaja mampu bergaul lebih matang dengan kedua jenis kelamin.

Pada masa remaja, remaja sudah seharusnya menyadari akan pentingnya pergaulan. Remaja yang menyadari akan tugas perkembangan yang harus dilaluinya adalah mampu bergaul dengan kedua jenis kelamin maka termasuk remaja yang sukses memasuki tahap perkembangan ini. Beberapa motivasi yang melatar belakangi seseorang merokok adalah untuk mendapat pengakuan, menghilangkan kekecewaan, dan menganggap perbuatannya tersebut tidak melanggar norma.

Hal ini sejalan dengan kegiatan merokok yang dilakukan oleh remaja yang biasanya dilakukan di depan orang lain, terutama dilakukan di depan kelompoknya karena mereka sangat tertarik kepada kelompok sebayanya atau dengan kata lain terikat dengan kelompoknya.

Lingkungan teman sebaya memberikan sumbangan efektif sebesar 93,8\% terhadap munculnya perilaku merokok pada remaja. Dalam penelitiannya dikatakan bahwa semakin banyak dukungan teman untuk merokok dapat mendorong seseorang untuk semakin menjadi perokok. Teman sebaya mempunyai peran yang sangat berarti bagi remaja, karena masa tersebut remaja mulai memisahkan diri dari orang tua dan mulai bergabung pada kelompok sebaya. Kebutuhan untuk diterima sering kali membuat remaja berbuat apa saja agar dapat diterima kelompoknya dan terbebas dari sebutan 'pengecut' dan 'banci'. Selanjutnya jika dilihat dari tahap-tahap perilaku merokok, teman sebaya dan keluarga merupakan fihak-fihak yang pertama kali mengenalkan atau mencoba merokok, kemudian berlanjut dan berkembang menjadi tobacco dependency atau adanya ketergantungan merokok. Dalam tahap ini maka merokok merupakan kepuasan psikologis dan bukan 
sematamata kebutuhan untuk mewujudkan simbolisasi kejantanan dan kedewasaan remaja.

Penguruh positif lain diterima dari teman sebaya. Hasil penelitian ini memperkuat penelitian yang dilakukan oleh Harlianti (1988) bahwa lingkungan teman sebaya memberikan sumbangan efektif sebesar 33,048\%. Lingkungan teman sebaya mempunyai arti yang sangat penting bagi remaja. Kebutuhan untuk diterima dan usaha untuk menghindari penolakan kelompok teman sebaya merupakan kebutuhan yang sangat penting. Remaja tidak ingin dirinya ditolak dan mengindari sebutan 'banci' atau 'pengecut'. Merokok bagi remaja juga merupakan simbolisasi, simbol atas kekuasaan, kejantanan, dan kedewasaan (Komasari, 2000).

\section{Budaya Perilaku Merokok Remaja}

Hasil analisa bivariat antara budaya dengan perilaku merokok menyatakan bahwa ada hubungan antara budaya dengan perilaku merokok, nilai $X^{2}=0,000<$ $\alpha=0,05$. Dari data yang diperoleh dapat diketahui bahwa remaja awalnya merokok karena mempunyai keinginan untuk mencoba. Kemudian mereka menjadi kecanduan terhadap rokok, karena menganggap rokok dapat menghilangkan stres, depresi, dan dapat memberikan rasa nikmat. Mereka mengetahui akan bahaya merokok, namun mereka tetap merokok karena telah kecanduan. Di lingkungan sekitar dan lingkungan keluarga mereka juga terdapat orang-orang yang merokok. Kebiasaan merupakan salah satu motif remaja menjadi perokok, dimana remaja tersebut menjadikan perilaku merokok sebagai sebuah perilaku yang harus tetap dilakukan tanpa adanya motif yang bersifat negatif ataupun positif. Remaja tersebut merokok hanya untuk meneruskan perilakunya tanpa tujuan tertentu. Selain itu remaja melakukan perilaku merokok ditujukan untuk mengikuti kebiasaan kelompoknya dan biasa terjadi pada masa remaja, identifikasi perokok lain, dan menentukan image diri (Levanthal, 1990).

Hampir sebagian remaja memahami akibat-akibat yang berbahay dari asap rokok tetapi mereka tidak menghindari dan tetap memilih melakoni perilaku tersebut. Ada banyak alsan yang melatarbelakangi perilaku merokok pada remaja, dan hal budaya atau kebiasaan yang berada di lingkungan remajalah yang juga banyak memberikan kontribusi mengapa remaja tersebut tetap memilih melakukan perilaku tersebut walaupun mereka benar-benar sadar akibat yang akan di dapatkannya. Dorongan teman sebaya, kebiasaan merokok yang dianggap biasa di lingkungan mereka, dan bahkan pujian yang dilontarkan kepada perokok yang menyatakan bahwa lelaki yang merokok adalah sosok yang tangguh itulah yang membuat remaja memilih melakoni perilaku tersebut.

Hal ini sependapat dengan penelitian Kur Lewin (2000), perilaku merokok merupakan fungsi dari lingkungan dan individu, artinya perilaku merokok selain disebabkan faktor-faktor dari dalam diri juga disebabkan oleh faktor lingkungan sekitar. Menurut Erikson (2000), remaja mulai merokok berkaitan dengan adanya aspek psikososial yag dialami pada masa perkembangannya yaitu masa ketika mereka sedang mencari jati dirinya. Lingkungan sosial buaya disinilah yang membawa pengaruh terhadap sikap, kepercayaan dan perhatian remaja pada rokok. Seseorang akan berperilaku merokok dengan memperhatikan lingkungan sosial budayanya (Smet, 1994). 


\section{SIMPULAN DAN SARAN \\ Simpulan}

Berdasarkan hasil penelitian dan analisis yang telah diuraikan dapat diambil kesimpulan sebagai berikut :

1. Sebagian besar responden berjenis kelamin perempuan, berusia 11-13 tahun dengan tingkat pendidikan Sekolah Menengah Pertama (SMP) sederajat.

2. Semua responden yang merokok berjenis kelamin laki-laki, berpendidikan SMP, dan berusia 14-15 tahun. Responden perokok memiliki keluarga, teman sebaya, guru, idola dan budaya (lingkungan sosial) yang mendukung perilaku merokok.

\section{Saran}

1. Bagi Masyarakat

Orangtua yang merokok hendaknya berhenti merokok atau tidak merokok didepan remaja. Teman sebaya memberikan kontribusi yang cukup besar kepada remaja untuk merokok, dalam hal ini jika orang tua tidak menginginkan anaknya merokok, maka orang tua perlu waspada terhadap kelompok teman sebaya anak-anaknya dan orang tua hendaknya mengawasi anaknya agar lebih selektif memilih teman yang bukan perokok.

2. Bagi pemerintah

Supaya membentuk tim pemantau pelaksaan peraturan KTR di setiap sekolah yang meliputi larangan untuk kegiatan merokok atau kegiatan memproduksi, menjual, mengiklankan, dan/atau mempromosikan produk tembakau serta pemberian sanksi kepada setiap yang melanggar.

3. Bagi Kementerian Kesehatan

Agar fokus dalam membina lingkungan bermain remaja yang mendukung remaja untuk menjauhi perilaku merokok dalam upaya menurunkan prevalensi merokok pada remaja. Memberlakukan secara tegas peraturan larangan merokok di tempat-tempat umum seperti di sekolah, kantor, dan sebagainya. Apabila ada pihak yang benar-benar melanggar peraturan tersebut diharapkan untuk segera diberikan sanksi atau tindakan tegas.

\section{DAFTAR PUSTAKA}

Aditama, TY.,(2006) Rokok dan Kesehatan. Jakarta: Universitas Indonesia.

Al Bachri. 1991. AdaApadengan Rokok. Available on http://sekolahindonesia .com. (Sitasi Tanggal 4 Maret 2013)

Baer \&Corado. (1999:294). Pengantar Psikologi. Atkinson.

Budiarjdo, Bagio. (1991). Remaja dan Masyarakat. Jakarta: PT Elex Media Komputindo Kelompok Gramedia.

Bustan. M., (2007). Epidemiologi Penyakit Tidak Menular. Rineka Cipta : Jakarta

Durkin, K (1995). Developmental Social Psychology, Massachussets:Blackwell Publisher Inc

Ekawati, E.R. (2012). Hubungan Kadar Glukosa darah Terhadap Hypertriglyceridemia Pada Penderita Diabetes Mellitus. Universitas Airlangga.

Erikson, E.H., (1963). Childhood and Society. New York: Norton \& Company

Gibney, Michael K et al. (2005) Gizi Kesehatan Masyarakat. Jakarta :Penerbit Kedokteran EGC.

Harlianti, T. T. (1988). Hubungan Antara Pemenuhan Kasih Sayang Orang Tua dan Pangaruh Lingkungan Merokok Teman Sebaya dengan Tingkah Laku Merokok remaja SMP.SkripsiFakultas Psikologi UGM Yogyakarta: Tidak diterbitkan.

Komasari, D., Helmi., A, F. (2000). Faktor-faktor Penyebab Perilaku Merokok Pada Remaja. Jurnal Psikologi N0. 1, 37-47.

Kurt, Lewin (1935). A Dynamic Theory of Personality. Selected Papers. New York: McGraw- Hill.

Leventhal, G.S., Karuza, J., \& Fry, W.R. 1980. Beyond Fairness: A Theory of Allocation Preferences. In G. Mikula (Editor), Justice and Social 
Interaction: 167-218, New York: Springer-Verlag.

Laventhal, H., Cleary.,(2000) The smoking problem: A review of The Reasearch and Theory in behavioral Rissk Modification. Psychological Bulletin, Vol. 88, No. 2, 370-405.

RISKEDAS,(2010).http://www.litbang.de pkes.go.id/sites/download/buku_lapor an/lapnas_riskesdas2010/Laporan_risk 2014) esdas_2010.pdf (sitasi 18 Desember

Shaluhiyah, Z., (2006) Sexual Lifestyle and Interpersonal Relationships of University Students in Central Java Indonesia and Theirs Implication for Sexual and Reproductive Health, in Phylosophy in Medical Geography. Exeter.

Smet, B., (1994) Psikologi Kesehatan. Penerbit PT Grasindo. Jakarta

UPTD Kabupaten Sampang Madura Jawa Timur , 2013/2014

WHO, (2013) World Health Statistics report. http://www.who.int /gho/publications/world_health_statistics/EN_W HS2013_Full.pdf (Sitasi 24 November 2014). 
Analisis Lingkungan Sosial Terhadap Perilaku....(Diah Wijayanti Sutha) 